Available online on 15.11.2018 at http://ujpr.org
Universal Journal of Pharmaceutical Research
An International Peer Reviewed Journal
Open access to Pharmaceutical research

\title{
ANTIDIABETIC AND ANTIHYPERLIPIDEMIC ACTIVITY OF DRACAENA CINNABARI BALF. RESIN ETHANOLIC EXTRACT OF SOQATRA ISLAND IN EXPERIMENTAL ANIMALS

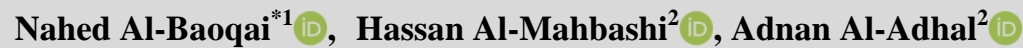 \\ ${ }^{I}$ Department of Pharmacology and Therapeutics, Faculty of Medicine and Health Sciences, Sana'a University, Yemen. ${ }^{2}$ Department of Forensic Medicine and Clinical Toxicology, Faculty of Medicine, Sana`a University, Yemen.
}

\section{ABSTRACT}

Objective: Dracaena cinnabari balf is a species plant in Agavaceae family. It is a tree endemic to the Island of Socotra, Yemen. It was used as a dye and medicine in Socotra and the Mediterranean basin. Some researches demonstrated both hypoglycemic and hypolipidemic of its resin of Dracaena cochinchinensis, a traditional Chinese tree. Accordingly, this study aimed to evaluate the antidiabetic potential of the ethanolic extract of Dracanea cinnabari balf resin (DCBR), endemic in Socotra Island, in Alloxan induced diabetes, and evaluation of possible antihyperlipidemic activity of the same extract in high-cholesterol diet-induced hyperlipidemia in male albino rats.

Methods: Experimental diabetes was induced in rats with intraperitoneal injection a single dose of Alloxan $(150 \mathrm{mg} / \mathrm{Kg})$. Hyperlipidemia was induced in rats by administration of $1 \%$ cholesterol in diet and $0.5 \%$ Hydrogen Peroxide in drinking water for 14 days. Fasting blood glucose levels were measured at $1^{\text {st }}$ day, $7^{\text {th }}$ day and $14^{\text {th }}$ day. Pancreas histopathology was done at the end. Estimation of serum lipid profile and liver histopathology was done at the end of 14 day. The results were expressed as mean \pm SD and differences among the groups of animals were compared using one-way ANOVA.

Results: Administration of ethanolic extract of resin of two doses (100 and 300 $\mathrm{mg} \backslash \mathrm{Kg}$ ) in alloxan induce diabetic rats resulted in a significant decrease in FBG levels with a recovery in destruction of pancreas cell compared with untreated group .Also the same doses of extract showed significant decrease in triglycerides, total cholesterol, low density lipoprotein, very low density lipoprotein and Atherogenic index in comparing with untreated group.

Conclusion: From the results of present study we can conclude the ethanolic extract of Dracaena cinnabari Balf. have a hypoglycemic and hypolipidemic activity in experimental animals , these activity are time and dose dependent.

Keywords: alloxan, blood glucose, diabetes, Dracanea cinnabari, flavonoids, glibenclamide, resin.

Article Info: Received 5 September 2018; Revised 12 October; Accepted 1 November, Available online 15 November 2018

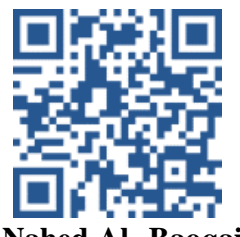

Cite this article-

Al- Baoqai N, Al-Mahbashi H, Al-Adhal A. Antidiabetic and antihyperlipidemic activity of Dracaena cinnabari Balf. Resin ethanolic extract of Soqatra Island in Experimental Animals. Universal Journal of Pharmaceutical Research 2018; 3(5): 1-10.

DOI: https://doi.org/10.22270/ujpr.v3i5.194

Address for Correspondence

Nahed Al- Baoqai, Department of Pharmacology and Therapeutics, Faculty of Medicine and Health Sciences, Sana'a University, Yemen. E-mail: Nahed.pharmacist@hotmail.com

\section{INTRODUCTION}

Diabetes mellitus is a group of metabolic disorders characterized by elevated levels of glucose in blood (hyperglycemia) due to insufficient production of insulin or because cells do not respond to insulin produced $^{1}$. It is estimated that about 350 million people have diabetes, the prevalence being similar in both high and low income countries and it is forecasted that global diabetes prevalence will increase by $50 \%$ in $2030^{2}$. The disease is characterized by increase production of oxygen-free radicals such as superoxide $\left(\mathrm{O}_{2}{ }^{-}\right)$, hydrogen peroxide $\left(\mathrm{H}_{2} \mathrm{O}_{2}\right)$, and hydroxide $\left(\mathrm{OH}^{-}\right)$ radicals and lack in antioxidant defense mechanisms which lead to increase oxidative stress and development of diabetes complications ${ }^{3}$. Management strategies of diabetes include life style intervention through diet modification and exercise and the use of oral hypoglycemic therapy and insulin treatment ${ }^{4}$.

Hyperlipidemia related to increased oxidative stress causing significant production of oxygen free radicals, which may lead to oxidative modifications in lowdensity lipoproteins, which present a significant function in the initiation and progression of atherosclerosis and associated cardiovascular diseases ${ }^{5}$. The treatments for hyperlipedemia vary according to factors that include heart disease risk, lipid levels and a patient's overall health. Potential treatments for lipid disorders include dietary changes, weight loss, regular 
exercise, quitting smoking, medications and periodic lipid screenings ${ }^{6}$. The chemical drugs used for treatment of hyperlipidemia are: statin, fibrates, In addition, other drugs, such as ezetimibe, colesevelam, torcetrapib, avasimibe, implitapide, and niacin are also being considered to manage hyperlipidemia ${ }^{7}$. Although the drugs are available in the market, long term use may cause a number of side effects. Hence a large number of studies are in progress to find natural sources, which are effective in reducing the intensity of diabetes and hyperlipidemia. World Health Organization (WHO) approved the use of plant drugs for different diseases ${ }^{8}$ including diabetes mellitus ${ }^{9}$ and hyperlipidemia $^{10}$. One of these plants is Dracanea cinnabari, known as Dam Al Akhawain. It is one of the rare and blessed tree in islet of Socotra, Yemen. Dracaena cinnabari balf is a species plant in Agavaceae family. It is a tree endemic to the Island of Socotra,Yemen ${ }^{11}$ the evocatively named dragon's blood tree has a unique and bizarre appearance, its upturned, densely-packed crown having the shape of an upside-down umbrella ${ }^{12}$. The name Dracaena is derived from the Greek word 'drakainia' meaning a female dragon). The most striking source is the Dracaena cinnabari balf. which is endemic to the island of Socotra (Yemen) ${ }^{\mathbf{1 3}}$. There are a lot of researches that have been worked on Dracena cinnabari balf resin and approved its effectiveness as a ntimicrobial, antiviral ${ }^{14}$, antitumor and cytotoxic ${ }^{15}$. It is also found that, it is a potent analgesic ${ }^{16}$, antioxidant ${ }^{17}$ and anti-inflammatory ${ }^{18}$. No previous studies about in vivo antidiabetic and antihyperlipedimec activity of Dracaena cinnabari balf resin that is a species plant endemic to the Island of Socotra, Yemen. Accordingly, the current study was done to prove the antidiabetic and antihyperlipedimec activity of Dracaena cinnabari balf resin ethanolic extract in experimental animals.

\section{METHODS}

\section{Chemicals and Instruments}

Alloxan 98\% (Hydrate) which was obtained from Oxford laboratory, India. Glibenclamide which obtained from DSM Sinochem pharmaceuticals, India. Auto analyzer performa- accuCheck Advantage II, Roche), Glucose kit from Roche, Germany. Cholesterol powder obtained from BDH chemicals LTD, England. Atorvastatin which obtained from DSM Sinochem pharmaceuticals, India. Hydrogen peroxide $30 \%$ obtained from EMPLURA (500ml) MERCK, India. Cholesterol. Triglyceride, HDL and LDL kits. HumaLyzer3500 photometers, Germany.

\section{Plant material}

Dracaena cinnabari balf resin is exuded and collected from incisions of the trunk of Dracaena cinnabari Balf.

\section{Preparation of ethanolic extract}

One kilogram of the Resin was washed thoroughly with distilled water, air-dried, powdered with an electrical grinder, and soaked in $99 \%$ ethanol (1:10) at room temperature $\left(25^{\circ} \mathrm{C}\right)$ over period of $48 \mathrm{hr}$ and were shaken several times (maceration method). The ethanol containing the extract was then filtered through Whitman paper then the solvent was vacuum distilled at $40^{\circ} \mathrm{C}$ in rotary evaporator. Final extract was red semi-solid in percentage dry weight $90 \%$. This ethanol extract was kept at $4^{0} \mathrm{C}$ until use.

\section{Experimental animals}

Healthy male albino rats of Wistar strain weighing 150-250g. They were obtained from the Central Animal House, Sana'a University. The present study was approved before start off experiment by the animal Ethics committee, 00243, Government of Yemen constituted, Sana'a University. The animals were housed in standard polypropylene cages and maintained within the same room temperature and humidity with 12:12 hour light and dark cycle. All the rats were given a 14-day period of acclimatization before starting the experiment.

\section{Induction of diabetes}

Diabetes was induced by intraperitoneal administration of a single dose of alloxan $(150 \mathrm{mg} / \mathrm{kg})^{\mathbf{2 0}}$. Male albino Rats were fasted for $18 \mathrm{~h}$. The fasting blood sugar (FBS) levels of the rats were determined with blood from the rats' tail vein using an auto analyzer (Accu Check Performa Advantage II, Roche). Freshly prepared Alloxan monohydrate dissolved in normal saline $(0.9 \% \mathrm{w} / \mathrm{v} \mathrm{NaCl})$ and injected as a single dose of $150 \mathrm{mg} / \mathrm{kg}$ intraperitoneally to induce hyperglycemia. To avoid fatal hypoglycemia as a result of massive pancreatic insulin release, rats were Kept for the next $24 \mathrm{~h}$ on $5 \%$ glucose $^{21}$. After 72 hours, rats with fasting blood glucose Level more than $250 \mathrm{mg} / \mathrm{dL}$ were considered to be diabetic and selected for studies ${ }^{22}$. The experiment was approved by the Institutional Ethical Committee, Faculty of Medicine and Health Sciences, Sana`a University.

\section{Experimental design}

Evaluation of antidiabetic activity of DCBR methanolic extract in alloxan-induced diabetic rats The albino rats were allocated randomly into five groups, each containing six rats:-

Group 1: Normal control, without treatment rats.

Group 2: Diabetic control, without treatment rats.

Group 3: Diabetic rats received Ethanolic extract (100 mg/Kg/day, p.o ${ }^{23}$.

Group 4: Diabetic rats received Ethanolic extract (300 mg/Kg/day, p.o.) $)^{\mathbf{2 3}}$

Group 5: Diabetic rats received glibenclamide (2.5 $\mathrm{mg} / \mathrm{Kg} /$ day, p.o. $)^{24}$.

After 72 hours from administration of alloxan rats with hyperglycemia more than $250 \mathrm{mg} \backslash \mathrm{dl}$ were selected and used for experiment. The rats were administered the extract (dissolved in Tween 80) and chemical drug for two weeks orally by using a feeding cannula. The experimental rats were weighed every day to compare the body weight change in different groups through the experimental period. FBG was estimated before the start of treatment, on $7^{\text {th }}$ day and $14^{\text {th }}$ days of treatment. All rats were later sacrificed on $14^{\text {th }}$ days by diethyl ether and the Pancreases were weighted separately then collected in $10 \%$ formalin for histopathological examination.

\section{Histopathological examination of Pancreas}

For histological study, specimens of pancreases were immersed in neutral buffered formalin (10\%) for 48 hours. Then tissue dehydration was done using 
ascending grades of alcohol (ethanol), followed by tissue clearing using xylene. The tissues were transferred to molten paraffin for impregnation and embedded in paraffin blocks. After fine sectioning, staining was done using hematoxylin and eosin $(\mathrm{H}$ and E) stain and examined under a microscope ${ }^{25}$. All the sections were examined under a light microscope under X400 magnifications. Photomicrographs of lesions were taken for observations and documentation of histopathological lesions.

Table 1: The effect of DCBR extract on change in the body weight (g) of Alloxan -induced diabetic rats.

\begin{tabular}{cccc}
\hline Groups & $\begin{array}{c}\mathbf{1}^{\text {st }} \text { Body } \\
\text { weight }(\mathbf{g})\end{array}$ & $\begin{array}{c}\mathbf{7}^{\text {th }} \text { day Body } \\
\text { weight }(\mathbf{g})\end{array}$ & $\begin{array}{c}\mathbf{1 4}^{\text {th }} \text { day Body } \\
\text { weight }(\mathbf{g})\end{array}$ \\
\hline Group 1 & $165.41 \pm 43.8$ & $196.46 \pm 32.7$ & $219.5 \pm 35.7$ \\
Group 2 & $178.33 \pm 17.4$ & $158.66 \pm 32.3$ & $146.73 \pm 36.3^{*}$ \\
Group 3 & $175.93 \pm 25.7$ & $184.48 \pm 26.5$ & $196.05 \pm 27.5$ \\
Group 4 & $153.16 \pm 43.1$ & $172.28 \pm 40.5$ & $187.73 \pm 39.0$ \\
Group 5 & $153 \pm 14.0$ & $150.56 \pm 19.9$ & $150.03 \pm 18.5^{*}$ \\
\hline \multicolumn{4}{c}{$\mathrm{N}=6$, Values are expressed as Mean $\pm S D ; * P \leq 0.05$ vs. group 1. } \\
\multicolumn{4}{c}{ DCBR: Dracanea cinnabari balf Resin. }
\end{tabular}

\section{Induction of hyperlipidemia}

Hyperlipidemia was induced in rats by administration of $1 \%$ cholesterol in diet and $0.5 \%$ Hydrogen Peroxide in drinking water for 14 days $^{26}$.

\section{Experimental design}

Evaluation of antihyperlipidemic activity of DCBR methanolic extract in experimental rats.

The albino rats were allocated randomly into five groups, each containing six rats :-

Group 1: Normal control, without treatment.

Group 2: Hyperlipidemic rats received 1\% cholesterol $+0.5 \%$ Hydrogen Peroxide

Group 3: Hyperlipidemic rats received 1\% cholesterol $+0.5 \%$ Hydrogen Peroxide and Ethanolic extract (100 $\mathrm{mg} / \mathrm{Kg} /$ day, p.o)

Group 4: Hyperlipidemic rats received $1 \%$ cholesterol $+0.5 \%$ Hydrogen Peroxide and Ethanolic extract (300 $\mathrm{mg} / \mathrm{Kg} /$ day, p.o).

Group 5: Hyperlipidemic rats received 1\% cholesterol $+0.5 \%$ Hydrogen Peroxide and Atorvastatin $(10 \mathrm{mg} / \mathrm{Kg} / \text { day, p.o })^{27}$.

After experimental period, and after an overnight fasting, animals in different groups were anesthetic under mild diethyl ether and the blood was withdrawn by retro-orbital method to determine serum lipid profile. Serum obtained by immediate centrifugation of blood samples using centrifuge at $3000 \mathrm{rpm}$ for $15 \mathrm{~min}$. at room temperature. The concentration of total cholesterol (TC), triglyceride (TG), high-density lipoprotein (HDL) and low-density lipoprotein (LDL) was determined by using enzymatic commercial kits marketed by QCA Ltd, Spain. While VLDL and atherogenic index in plasma was calculated as per Friedewald estimation $^{28}$. Then, the animals were sacrificed to take the liver and aorta specimens for histopathological examination.

Histopathological examination of liver and Aorta Specimens of liver and aorta were immersed in neutral buffered formalin (10\%) for 48 hours. Then tissue dehydration was done using ascending grades of alcohol (ethanol), followed by tissue clearing using xylene. The tissues were transferred to molten paraffin for impregnation and embedded in paraffin blocks. After fine sectioning, staining was done using hematoxylin and eosin $(\mathrm{H}$ and $\mathrm{E})$ stain and examined under a microscope ${ }^{25}$. All the sections were examined under a light microscope under X400 magnifications. Photomicrographs of lesions were taken for observation and documentation of histopathological lesions.

\section{Statistical analysis}

The results were expressed as mean \pm SD and differences among the groups of animals were compared using one-way ANOVA with post-hoc LSD's test. Statistical significance was set at $P \leq 0.05$. Statistical analysis was performed using Microsoft excel, and SPSS software version 20.

Table 2: The effect of DCBR extract on change in the pancreas weight (g) of Alloxan-induced diabetic rats.

\begin{tabular}{ccc}
\hline Groups & $\begin{array}{c}\text { pancreas weight } \\
\text { (g) mean } \pm \text { SD }\end{array}$ & $\begin{array}{c}\text { \% of change } \\
\text { vs. group 1 }\end{array}$ \\
\hline Group 1 & $1.57 \pm 0.43$ & \\
Group 2 & $0.48 \pm 0.08^{*}$ & $69.4 \%$ \\
Group 3 & $1.03 \pm 0.42$ & $34.3 \%$ \\
Group 4 & $1.33 \pm 0.43^{* *}$ & $15.3 \%$ \\
Group 5 & $0.92 \pm 0.21 *$ & $41.4 \%$ \\
\hline
\end{tabular}

$\mathrm{N}=6$, Values are expressed as Mean $\pm \mathrm{SD} ; * P \leq 0.05$ vs. group 1 , $* * P \leq 0.05$ vs. Group 2. DCBR: Dracanea cinnabari balf Resin.

\section{RESULTS}

Result of antidiabetic activity of DCBR methanolic extract in alloxan-induced diabetic rats.

\section{Relative change in body weight}

Measurement of the weight of all animals from the first day to the last day of the experiment showed an irregular change and differences in the groups as shown in Table 1. The weight of group 1 increased significantly from 1 st day to $14^{\text {th }}$ day in opposite to group 2. While, the groups that treated with 100 $\mathrm{mg} / \mathrm{Kg}$ (group 3) and $300 \mathrm{mg} / \mathrm{Kg}$ DCBR extract (group 4) showed noticeable improvement to normal weight during treatment period whereas the weight were dropped dramatically because of Alloxan injection. Group 5 that was treated with $2.5 \mathrm{mg} / \mathrm{Kg}$ Glibenclamide kept the same weight level during treatment period.

Relative change in weight of pancreas:

As shown in Table 2, after 14 day of treatment, there was a significant decrease in pancreas weight in group 2 , in comparison to group 1 (p-value $\leq 0.05)$. Group 3 which was treated with $100 \mathrm{mg} / \mathrm{Kg}$ DCBR extract showed an increase in pancreas weight. We got the same result with group 5 which was treated with 2.5 $\mathrm{mg} / \mathrm{Kg}$ Glibenclamide, whereas group 4 which was treated with $300 \mathrm{mg} / \mathrm{Kg}$ DCBR extract, showed a significant increase in the pancreas weight in comparison to group 2.

Biochemical investigation (FBG)

The groups 2, 3, 4 and 5 which were injected with $150 \mathrm{mg} / \mathrm{Kg}$ alloxan showed a significant increase in the 
FBG values more than $200 \mathrm{mg} / \mathrm{dl}$ (p-value $\leq 0.05$ ) in comparison to group 1. After 7 days of treatment, the dose of $100 \mathrm{mg} / \mathrm{Kg}$ DCBR extract(group 3) , 300 $\mathrm{mg} / \mathrm{Kg}$ DCBR extract (group 4) and $2.5 \mathrm{mg} / \mathrm{Kg}$ Glibenclamide (group 5) showed a significant change in comparison to group 1 and group 2 ( $p$-value $\geq 0.05)$, as well as after 14 days of treatment. By the way, group 4 did not show a significant change in FBG in comparable to group 1, which means that $300 \mathrm{mg}$ $\mathrm{mg} / \mathrm{Kg}$ DCBR extract dose, achieved the target normal value of FBG (Table 3).

Table 3: Effects of DCBR extract on the FBG values (mg/dl) of Alloxan-induced diabetic rats.

\begin{tabular}{|c|c|c|c|c|c|}
\hline Groups & $\begin{array}{c}\text { Basal } \\
\text { Value(mg/dl) }\end{array}$ & $7^{\text {th }}$ day $(\mathrm{mg} / \mathrm{dl})$ & $\begin{array}{c}\% \text { of FBG change } \\
\text { vs. Basal Value after } \\
7 \text { days }\end{array}$ & $14^{\text {th }} \operatorname{day}(\mathrm{mg} / \mathrm{dl})$ & $\begin{array}{c}\text { \% of FBG change vs. } \\
\text { Basal Value after } 14 \\
\text { day }\end{array}$ \\
\hline Group 1 & $80.16 \pm 9.7$ & $88.16 \pm 4.2$ & & $90.3 \pm 6.7$ & \\
\hline Group 2 & $495.0 \pm 32.7 *$ & $522.16 \pm 31.1 *, \Delta$ & & $508.4 \pm 34.9^{*, \Delta}$ & \\
\hline Group 3 & $381.6 \pm 22.2 * * *$ & $291.8 \pm 18.1 * * *, \Delta$ & $24 \%$ & $180.8 \pm 14.9 * * *, \Delta$ & $53 \%$ \\
\hline Group 4 & $473.6 \pm 14.7 *$ & $186.6 \pm 4.4 * * *, \Delta$ & $60.5 \%$ & $101.6 \pm 3.1 * *, \Delta$ & $79 \%$ \\
\hline Group 5 & $481.5 \pm 11.4^{*}$ & $415.0 \pm 13.7 * * *, \Delta$ & $14 \%$ & $217.0 \pm 10.7 * * *, \Delta$ & $55 \%$ \\
\hline
\end{tabular}
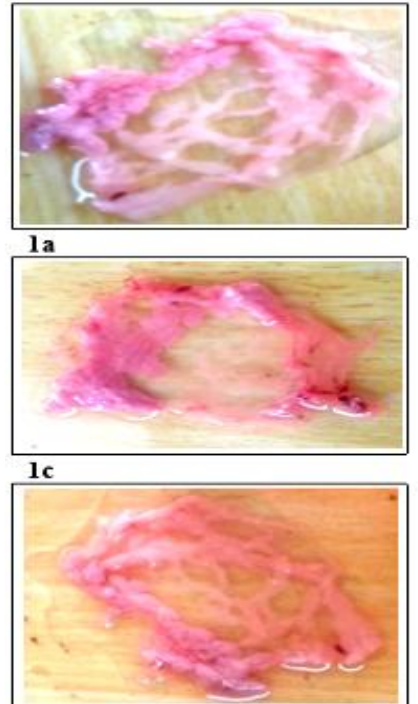

le

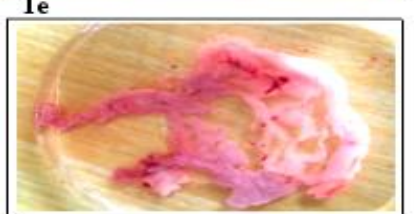

$1 \mathrm{~g}$

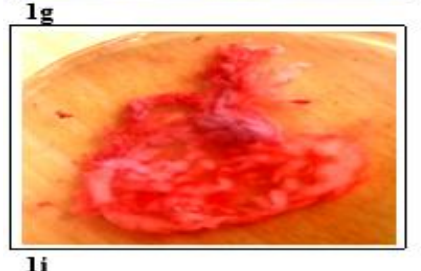

$1 i$
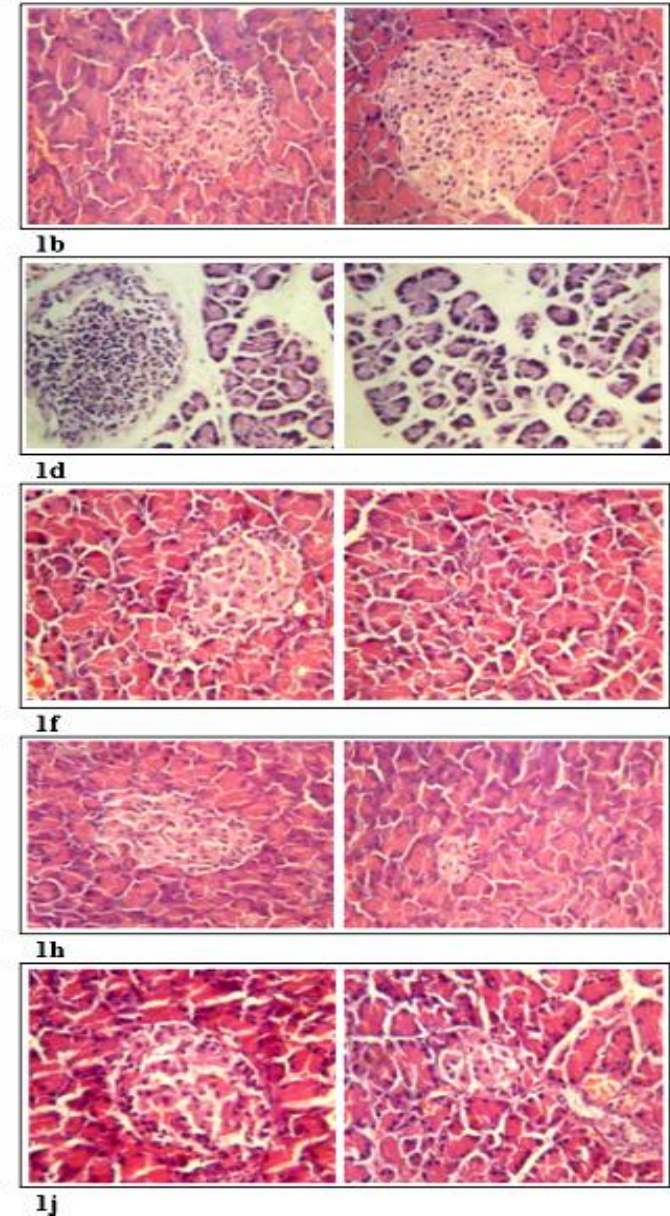

$1 \mathbf{j}$

Figure 1: Macroscopic and microscopic observation of pancreas in rats.

Macroscopic images: 1a: group 1, 1c: group 2, 1e: group 3, 1g: group 4, 1i: group 5

Microscopic images: Hematoxylin and eosin staining of pancreatic islets of group 1, group 2, group 3, group 4 and group 5 (1b), (1d), (1f), (1h), respectively. Observe islet cells with defined boundaries (black arrow) in (1b), (1f), and (1j), when compared with (1d) X400

Table 4: The effect of DCBR extract on change in the body weight (g) of hyperlipidemic rats.

\begin{tabular}{cccc}
\hline Groups & $\begin{array}{c}\text { Initial Body } \\
\text { weight }(\mathbf{g})\end{array}$ & $\begin{array}{c}\mathbf{7}^{\text {th }} \text { day body } \\
\text { weight }(\mathbf{g})\end{array}$ & $\begin{array}{c}\mathbf{1 4}^{\text {th }} \text { day Body } \\
\text { weight }(\mathbf{g})\end{array}$ \\
\hline Group 1 & $251.33 \pm 22.5$ & $271.48 \pm 19.7$ & $295.01 \pm 15.5$ \\
Group 2 & $277.9 \pm 6.6$ & $279.25 \pm 2.1$ & $287.3 \pm 0.6$ \\
Group 3 & $295.4 \pm 32.1$ & $293.4 \pm 34.2$ & $305.46 \pm 32.6$ \\
Group 4 & $321.3 \pm 43.3$ & $279.41 \pm 37.5$ & $280.98 \pm 42.4$ \\
Group 5 & $306.53 \pm 35.9$ & $300.26 \pm 30.4$ & $316.38 \pm 34$ \\
\hline
\end{tabular}

$\mathrm{N}=6$, Values are expressed as Mean $\pm \mathrm{SD} ; * P \leq 0.05$ vs. group 1 . DCBR: Dracanea cinnabari balf Resin. 

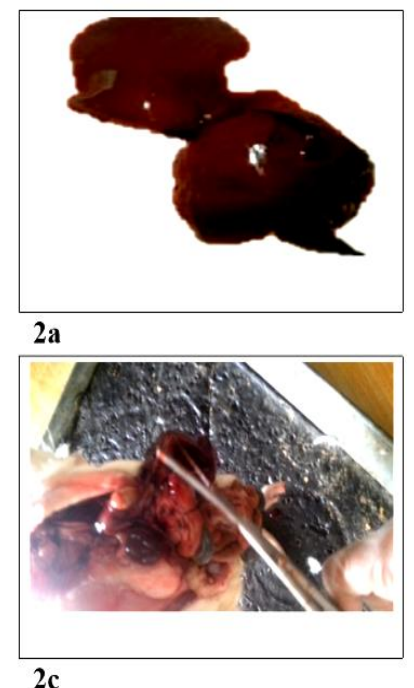

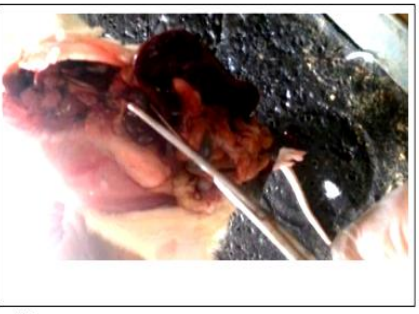

2b

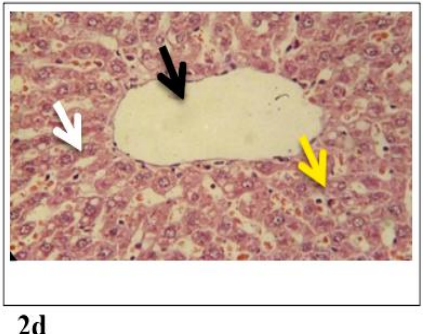

Figure 2: Macroscopic and microscopic observation of liver in rats (group 1).

2a: Macroscopic image of normal liver; $\mathbf{2 b}$ and 2c: Adipose tissue around the liver (black arrow); 2d: Microscopic section of normal liver stained by hematoxylin-eosin shows portal vein (black arrow), hepatic cord (white arrow) and hepatic sinuside (yellow arrow) X400.

\section{Histopathological examination of pancreas Macroscopic observations}

The pancreas was subjected to macroscopic and microscopic investigation to detect irregularities and abnormalities of the structure. Macroscopic analysis of the control group demonstrated normal pinkish appearance (Figure 1a) in comparison to the pancreas of untreated diabetic, depletion large area of the pancreas as a result of alloxan injection $150 \mathrm{mg} / \mathrm{Kg}$, (Figure 5c). Treated groups with $300 \mathrm{mg} / \mathrm{Kg}$ extract, $100 \mathrm{mg} / \mathrm{Kg}$ extract, and $2.5 \mathrm{mg} / \mathrm{Kg}$ Glibenclamide showed clear preserved tissue (Figure 1e, Figure 1g, and Figure 1i) respectively).

\section{Microscopic observations}

The microscoic appearance of the control group islet cells (group 1) was normal (Figure 5b). Untreated diabetic group (group 2) revealed a breakdown of micro-anatomical features including necrosis as in (Figure: 1d). The comparison of the untreated diabetic group to normal group, there was destruction in the islet cells with irregular shape and atrophy (Figure: 1d). (Figure: 1f, $1 \mathrm{~h}$ and $1 \mathrm{j}$ ) figures showed treated diabetic rats with $100 \mathrm{mg} / \mathrm{Kg}$ extract (group 3), $300 \mathrm{mg} / \mathrm{Kg}$ extract (group 4) and $2.5 \mathrm{mg} / \mathrm{Kg}$ Glibenclamide (group $5)$ respectively. The comparison of these three groups with the untreated diabetic rats, there was an evidence of recovery of Langerhans islets, more obvious islet pattern with well outlined boundaries, vacuolation was reduced or absent in many islets.

Result of antihyperlipidemic activity of DCBR methanolic extract in experimental rats.

- Relative change in body weight

Based on the result reflected on Table 4, we could say that the rats of groups 2,3,5 (hyperlipidemic without treatment, $100 \mathrm{mg} / \mathrm{Kg}$ DCBR extract, $10 \mathrm{mg} / \mathrm{Kg}$ Atorvastatin respectively, showed an increased growing in body weight throughout the entire period of treatment. However, there was a decrease in group 4 which was treated with $300 \mathrm{mg} / \mathrm{Kg}$ DCBR extract.
Table 5: The effect of DCBR extract on change in the liver weight $(\mathrm{g})$ of hyperlipidemic rats.

\begin{tabular}{ccc}
\hline Groups & $\begin{array}{c}\text { liver weight }(\mathrm{g}) \\
\text { mean } \pm \text { SD }\end{array}$ & $\begin{array}{c}\text { \% of change } \\
\text { vs. group 1 }\end{array}$ \\
\hline Group 1 & $9.65 \pm 0.25$ & \\
Group 2 & $16.9 \pm 0.91^{*}$ & $43 \%$ \\
Group 3 & $10.4 \pm 1.08^{* *}$ & $7.8 \%$ \\
Group 4 & $11.13 \pm 1.09^{* *}$ & $13 \%$ \\
Group 5 & $13.21 \pm 2.36^{* * * *}$ & $27 \%$ \\
\hline
\end{tabular}

$\mathrm{N}=6$, Values are Mean $\pm \mathrm{SD} ; * P \leq 0.05$ vs. group $1, * * P \leq 0.05$ vs. group 2. DCBR: Dracanea cinnabari balf Resin

- Relative change in weight of liver

As shown in Table 5, after 14 days of treatment, there was a significant change in the liver weight of group 2 in comparison to group 1 ( $\mathrm{p}$-value $\leq 0.05$ ). Also, other three groups of treatment with $100 \mathrm{mg} / \mathrm{Kg}$ DCBR extract (group 3), $300 \mathrm{mg} / \mathrm{Kg}$ DCBR extract (group 4) and $10 \mathrm{mg} / \mathrm{Kg}$ Atorvastatin (group 5) showed a significant change and decrease the liver weight in comparison to group 2 ( $\mathrm{p}$-value $\leq 0.05)$.

Biochemical parameters: TC, TG, HDL, LDL, VLDL, and AI

As in Table 6 the rats when fed with high-fat diet (1\% cholesterol) showed a remarkable hyperlipidemia. For the whole group, there was a significant increase in TC, TG, LDL, VLDL Al, and a decrease in HDL in comparison to group1 (p-value $\leq 0.05$ ). When we compare the treated groups with group 2, we noticed that: the treated group with $100 \mathrm{mg} / \mathrm{Kg}$ DCBR extract(group 3) showed a significant decrease in TC, TG, LDL,VLDL and AI and a significant increase in HDL $\quad(p$-value $\leq 0.05)$, (where the change in TC,TG,LDL was insignificant, and VLDL was significant). The higher dose of $300 \mathrm{mg} / \mathrm{Kg}$ DCBR extract (group 4) showed a significant effect in decreasing TC, TG, LDL, and AI. In addition, there is no effect on HDL. The last group which was treated with $10 \mathrm{mg} / \mathrm{Kg}$ Atorvastatin showed no effect on TC, TG. But, also showed a significant increase in HDL and no significant effect on VLDL and AI. 
Table 6: Effects of DCBR extract on the lipid profile mg/dl of high fat diet hyperlipidemic rats after 14 days.

\begin{tabular}{ccccccc}
\hline Groups & TC & TG & HDL & LDL & VLDL & AI \\
\hline Group 1 & $59.2 \pm 13.51$ & $103.98 \pm 20.5$ & $52.48 \pm 5.83$ & $73.5 \pm 14.54$ & $20.79 \pm 4.1$ & $1.13 \pm 0.25$ \\
Group 2 & $111.5 \pm 9.31^{*}$ & $136 \pm 2.19^{*}$ & $28 \pm 1.09^{*}$ & $130.5 \pm 7.12^{*}$ & $27.2 \pm 0.43^{*}$ & $3.97 \pm 0.17^{*}$ \\
Group 3 & $93.46 \pm 9.98^{* *}$ & $107 \pm 8.19^{* *}$ & $36 \pm 3.89^{* *}$ & $119.66 \pm 12.2$ & $21.4 \pm 1.63^{* *}$ & $2.63 \pm 0.51^{* *}$ \\
Group 4 & $77.01 \pm 8.84^{* *}$ & $96.08 \pm 23.61^{* *}$ & $28 \pm 0.63$ & $102.16 \pm 4.75^{* *}$ & $19.21 \pm 4.72 * *$ & $2.74 \pm 0.28^{* *}$ \\
Group 5 & $113.05 \pm 11.83$ & $134 \pm 3.63$ & $37.5 \pm 3.27 * *$ & $121 \pm 10.31$ & $26.8 \pm 0.72$ & $3.02 \pm 0.28^{* *}$ \\
\hline
\end{tabular}

$\mathrm{N}=6$, Values are expressed as Mean \pm SD; $* P \leq 0.05$ vs. group $1, * * P \leq 0.05$ vs. group 2 . DCBR: Dracanea cinnabari balf Resin, TC: Total Cholesterol, TG: Triglyceride, HDL: High Density Lipoprotein, LDL: Low Density Lipoprotein, VLDL: Very Low Density Lipoprotein, AI: Atherogenic Index.

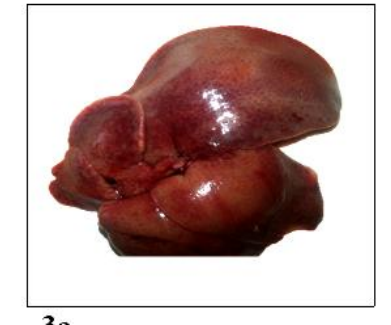

$3 \mathbf{a}$

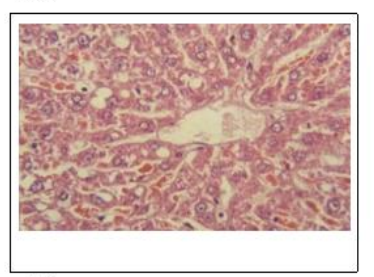

$3 d$

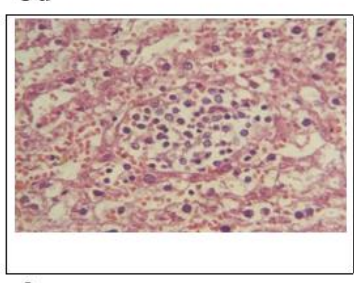

$3 g$

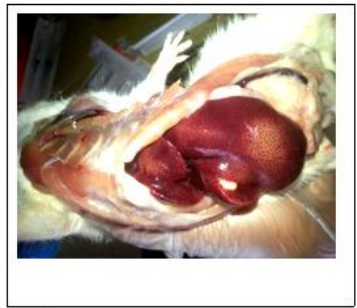

$3 \mathbf{b}$

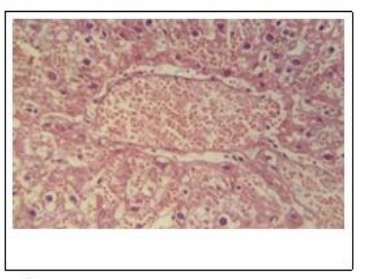

$3 e$

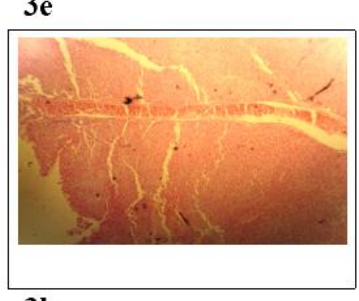

$3 \mathbf{h}$

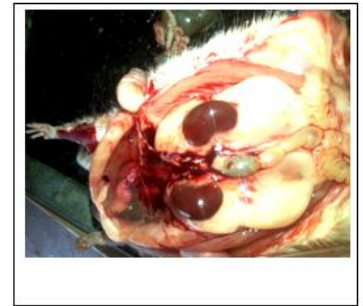

$3 c$

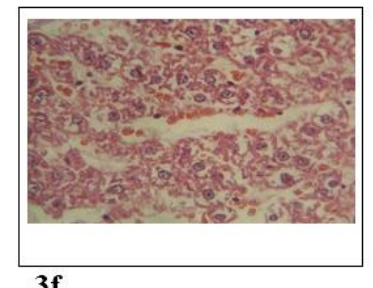

$3 \mathbf{f}$

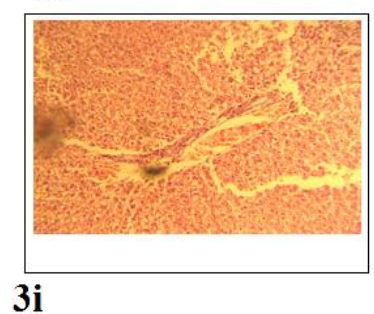

Figure 3: Macroscopic and microscopic observation of liver in rats (group 2).

3a and 3b: Macroscopic image of high fat liver; 3c: Adipose tissue around the liver; 3d, 3e, 3g, 3g, 3h, and 3i: Microscopic image shows abnormal liver structure i.e. 3d: Fatty changes, 3e: Haemorrhage, 3f: Hydrobic changes, 3g: Inflammation, 3h:

Vasodilatation, 3i: Infiltration, X400

\section{Histopathological examination of liver and Aorta Macroscopic observations}

The liver was subjected to macroscopic and microscopic investigation to detect irregularities and abnormalities of the structure. Macroscopic analysis of the liver in hyperlipidemic group (group 2) demonstrated major light brown color changes of the liver lobes (Figure 3a, and Figure 3b). While the liver of the normal group (group 1) looks in a normal appearance i.e. deep brown color with smooth surface (Figure 2a). The hyperlipidemic groups treated with $100 \mathrm{mg} / \mathrm{Kg}$ DCBR extract (group 3), $300 \mathrm{mg} / \mathrm{Kg}$ DC extract (group 4), and $10 \mathrm{mg} / \mathrm{Kg}$ Atorvastatin (group 5) showed pale brown coloration of the hepatic soft tissue (Figure: 4a, 4d and 4g). In addition, inducing high fat diet shows a clear accumulation of fat in the adipose tissue inside the rat abdomen. Which is clear in group 2 (Figure: $3 \mathrm{~b}$ and 3c). The treated group with $100 \mathrm{mg} / \mathrm{Kg}$ DC extract shows no big difference in the amount of the accumulation of the fat in adipose tissue
(Figure: 4b). Whereas other doses of $300 \mathrm{mg} / \mathrm{Kg} \mathrm{DC}$ extract and $10 \mathrm{mg} / \mathrm{Kg}$ Atorvastatin shows a notable decrease Figure 4.

\section{Microscopic observations}

The normal liver tissue section of group 1 shows normal structure i.e portal vein, hepatic cord, and hepatic sinuside (Figure 2d). Whereas the hyperlipidemic rat liver tissue section (group 2) shows distortion in the arrangement of cells around the central vein, inflammation Figure $3 g$, infiltration Figure 3i, fatty changes Figure $3 \mathrm{~d}$, hemorrhage Figure $3 \mathrm{e}$, hydropic change Figure $3 \mathrm{f}$, vasodilation Figure $3 \mathrm{~h}$. The hyperlipidemic groups treated with $100 \mathrm{mg} / \mathrm{Kg} \mathrm{DC}$ extract (group 3), $300 \mathrm{mg} / \mathrm{Kg} \mathrm{DC}$ extract (group 4) and $10 \mathrm{mg} / \mathrm{Kg}$ Atorvastatin ( Group 5) brought back the cellular arrangement around the vein in some parts of the tissue that lead to bring the blood vessels to the normal conditions (Figure 4c, Figure 4f and Figure 4i respectively). Histopathological picture of Aorta all groups does not show any abnormalities Figure 5. 


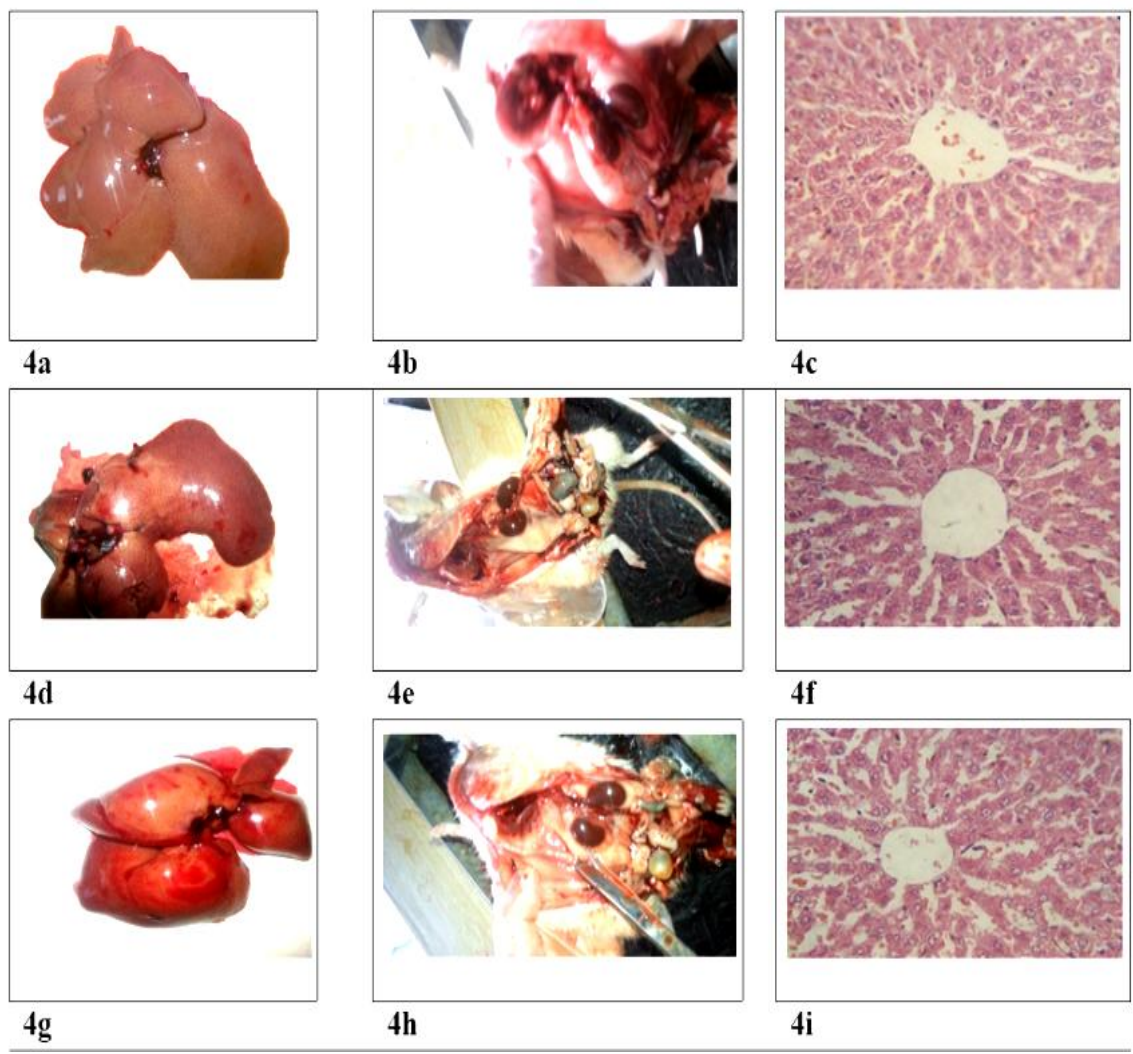

Figure 4: Macroscopic and microscopic observation of liver in rats (group 3, 4 and 5).

4a, 4d, 4g: Macroscopic images of liver of group 3, 4, and 5.

$\mathbf{4 b}, \mathbf{4 e}, \mathbf{4 h}$ : Adipose tissue around the liver of group 3, 4, 5 respectively.

4c, 4f, 4i: Microscopic image shows regeneration of abnormal liver structure with the same sequence group 3, 4, and 5. X400

\section{DISCUSSION}

Alloxan can induce diabetes by destruction of the beta cells of the islets of Langerhans of the pancreas ${ }^{29}$. This results in a decrease of endogenous insulin secretion which paves way for the decreased utilization of glucose by body tissues and consequently elevation of blood glucose level ${ }^{30}$. In current study and after alloxan injection, elevation of blood glucose was observed in group 2, 3, 4 and 5. When treated them with the ethanolic extract of $D$ cinnabari, it was indicated that all of them reduced the blood glucose level to an extent. The dose $100 \mathrm{mg} / \mathrm{Kg}$ decreased FBG significantly $(\mathrm{p} \leq 0.05)$ up to $24 \%$ and $53 \%$ after 7,14 day respectively. Also, the dose $300 \mathrm{mg} / \mathrm{Kg}$ showed more decrease in FBG significantly $(\mathrm{p} \leq 0.05)$ up to $60.5 \%$ and79 \% after 7 and 14 days respectively. These results were compatible with Chen et al., ${ }^{31,23}$. They demonstrated hypoglycemic effect of total flavonoids of Dracaena cochinchinensis in type 2 diabetes mellitus rats ${ }^{31}$. Also, Gu et al., showed an antidiabetic effect of Dracaena Cochinchinensis by inhibition on alpha-glucosidase activity and suppressing intestinal carbohydrate absorption and thereby reducing the postprandial increase of blood glucose $^{23}$. In an in vitro study reported the ethyl acetate extract of Dragon cinnabari resin has antidiabetic properties with standard glucose uptake procedure against MCF-7 cell line ${ }^{19}$. The mechanism of antidiabetic properties of the extract is not well known. But, it is returned likely to the phytochemical constituents including flavonoids, alkaloids, tannins, and others. Theses constitutes also obtained from various plant sources and they have been reported to be potent hypoglycemic agents ${ }^{32}$. Flavonoids are the main chemical constituents of dracaena species ${ }^{31,33,34}$.

Flavonoids derivative from the methanoilc extract of Origanum majorana L. (family: Lamiaceae) leaves have $\alpha$-glucosidase enzyme inhibitory activity ${ }^{38}$. Another flavonoids from Cecropia obtusifolia (family: Ceropiaceae) exhibited potent hypoglycemic activity comparable to that of glibenclamide at a dose of 3 $\mathrm{mg} / \mathrm{kg}$ in diabetic rats ${ }^{39}$. Other flavonoids were isolated from the dried leaves of Myrcia multiflora DC. (family: Myrtaceae) inhibited the activity of the rat lens aldose reductase enzyme so decrease diabetic complications ${ }^{40}$. Flavonoids isolated from Eysenhardtia platycarpa (family: Leguminosae) were evaluated to possess promising anti-hyperglycemic activity by decreasing glucose level of streptozotocin (STZ)- induced diabetic rats $(31 \mathrm{mg} / \mathrm{Kg} \text { of body weight, } \mathrm{P}<0.05)^{41}$.

In addition, leaves of Eucommia ulmoides (family: Eucommiaceae) has flavonoid which inhibit glycation end-product formation, one of main molecular mechanisms implicated in diabetic complications ${ }^{42}$. Flavonoids can decrease the blood glucose by pancreatic and extra pancreatic mechanisms. They can act as insulin secretagogues which increase insulin secretion in vitro and in vivo systems ${ }^{43,38}$. in similar to Sulfonylureas such as glibenclamide ${ }^{44}$ which was used as the reference drug in this study. They also can inhibit $\alpha$-glucosidase activity in the intestine and reduce glucose absorption from intestine ${ }^{23}$. 


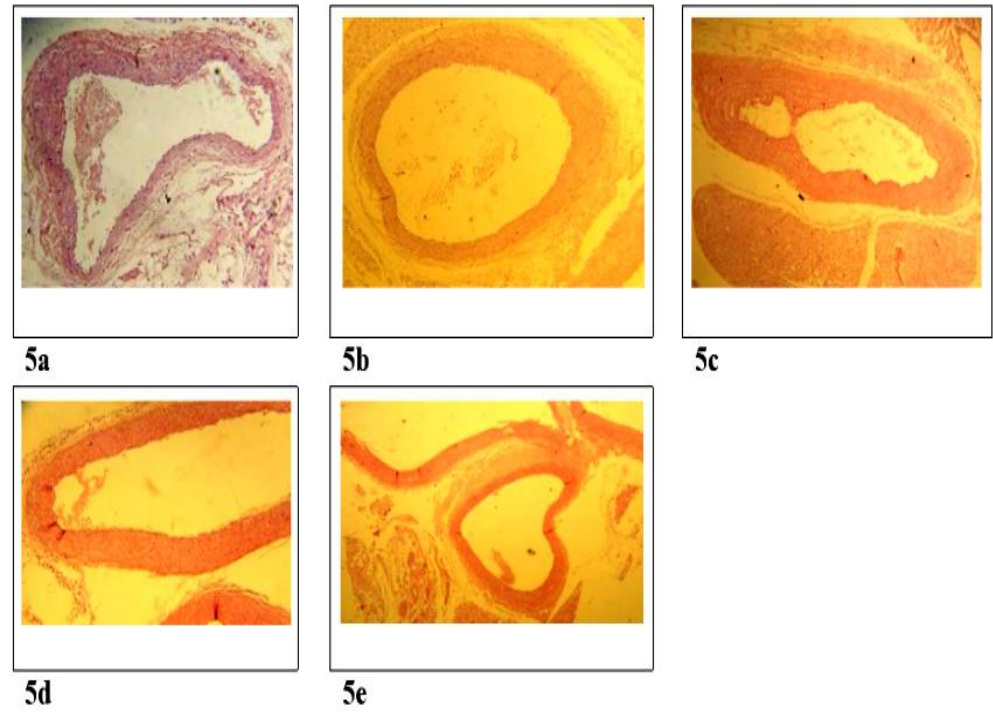

Figure 5: Microscopic observation of aorta in rats.

5a: group 1, 5b: group 2, 5c: group 3, 5d: group 4, 5e: group 5. X400

There are convincing experimental and clinical evidence that the generation of ROS is increased in both Type 1 and Type 2 diabetes and that the onset of diabetes is closely associated with oxidative stress ${ }^{45}$. Flavonoids are rich in phenol groups which work as antioxidant which may have slowed or terminated the production of ROS thereby reversing the diabetic condition $^{17,46,47,48}$. In the histopathology, the degeneration observed in the pancreas of alloxaninduced diabetic rats may be due to necrotic action of alloxan on the beta cells ${ }^{49,50}$. The degenerative changes induced by alloxan in rats pancreas were recovered by DCBR extract and glibenclamide which was followed by regeneration of the islet cells and increased tissue density with attendant improved insulin production and reduction of FBG in rats. This effect was more pronounced at $300 \mathrm{mg} / \mathrm{kg}$ DCBR extract. It has been demonstrated that beta cells can regenerate from stem cells located in pancreatic ducts or from progenitor cells residing inside murine islets ${ }^{51}$. Regeneration of the islet cells by DCBR extract may involve promotion of the above mechanisms. Also, Flavonoids are reported to regenerate the damaged pancreatic $\beta$-cells in diabetic animals which were acting as antioxidant and reducing the cells damage by alloxan ${ }^{52}$. Furthermore, the current study showed antihyperlipidemic effect of DCBR extract which is agreed with Fan et al., ${ }^{34}$. High fat diet administered to rats raised the lipid profile and with treatment by extract, lipids are decreased by $16 \%, 31 \%$ TC. $21 \%$, $29 \%$ TG. $8 \%$, 22\% LDL. $21 \%$, 29\% VLDL with 100 $\mathrm{mg} / \mathrm{kg}$ and $300 \mathrm{mg} / \mathrm{Kg}$ respectively. and decrease athereogenic index which is an indicator to decrease the atherosclerosis risks. Increase HDL to $25 \%$ with $100 \mathrm{mg} / \mathrm{Kg}$ dose with no effect with the dose 300 $\mathrm{mg} / \mathrm{kg} .10 \mathrm{mg} / \mathrm{Kg}$ of atorvastatin which was used as a reference drug did not show effect on TC and TG.

atorvastatin works by inhibiting HMG-CoA reductase, an enzyme found in liver tissue that plays a key role in production of cholesterol in the body. While the outer source of lipid was continuous in food, may this interpret the lack effect of atorvastatin. Various mechanisms can be explained how flavonoids, which is the main component of Dracaena cinnabari, decreased the lipid profile. Hyperlipidemia related to increased oxidative stress causing significant production of oxygen free radicals, which may lead to oxidative modifications in low-density lipoproteins, which present a significant function in the initiation and progression of atherosclerosis and associated cardiovascular diseases ${ }^{5}$. Flavonoids can act directly as scavenging some radical species, thus acting as antioxidants and inhibit the progression of atherosclerosis ${ }^{47}$. Flavonoids can bind with bile acids. Since these resin are not absorbed, bile acids are excreted. This results in a decreasing bile acid uptake by the liver, and therefore in a higher conversion of cholesterol to bile acids in the liver ${ }^{53}$. Also, flavonoids can Inhibit Pancreatic cholesterol esterase enzyme ,therefore limit the absorption of dietary cholesterol $^{54,55,53}$ then reduce the solubility of cholesterol in micelles which may result in delayed cholesterol absorption ${ }^{56,54}$. The histopathological finding of liver showed an enhancement in some parts of the tissue, because of the effect of the extract in reducing blood lipid. By the way, long-term treatment is required for regeneration the whole tissue.

In conclusion, ethanolic DCBR extract has demonstrated significant antidiabetic and antihyperlipidemic activity. This effect is dose and time dependent. This effect is may be due to the presence of flavonoids in the whole extract, which are working by different mechanisms. However, further studies are recommended to isolate and elucidate the bioactive compound(s) responsible for its antidiabetic and antihyperlipidemic activity and its molecular mechanism of action.

\section{ACKNOWLEDGEMENTS}

Many thanks to all who contributed to the completion of this work, and especially to IDB Scholarship Programs and Zoology department, Faculty of Science. 


\section{AUTHOR'S CONTRIBUTION}

The manuscript was carried out, written, and approved in collaboration with all authors.

\section{CONFLICT OF INTEREST}

No conflict of interest associated with this work.

\section{REFERENCES}

1. Barik R, Jain S, Qwatra D, Joshi A, Tripathi GS, Goyal R. Antidiabetic activity of aqueous root extract of Ichnocarpus frutescens in streptozotocin-nicotinamide induced type-II diabetes in rats. Indian J Pharmacol 2008; 40(1):19-22. https://doi.org/10.4103/0253-7613.40484

2. Wild S, Roglic G, Green A, Sicree R, King H. Global prevalence of diabetes: estimates for the year 2000 and projections for 2030. Diabetes Care 2004; 27(5): 1047-53. https://doi.org/10.2337/diacare.27.5.1047

3. Giacco F, Brownlee M. Oxidative stress and diabetic complications. Circ Res. 2010; 107(9);1058-70.

https://doi.org/10.1161/circresaha.110.223545

4. Holman RR, Paul SK, Bethel MA, Matthews DR, Neil HAW. 10-year follow-up of intensive glucose control in type 2 diabetes. N Engl J Med 2008; 359(15):1577-89. https://doi.org/10.1056/NEJMoa0806470

5. Mishra PR, Panda PK, Chowdary KA. Evaluation of acute hypolipidemic activity of different plant extracts in Triton Wr-1339 I induced hyperlipidemia in albino rats 2011; 934:925-934. https://doi.org/10.1016/j.apjtm.2016.03.038

6. Rosenthal RL. Effectiveness of altering serum cholesterol levels without drugs. Proc (Bayl Univ Med Cent) 2000; 13(4):351-5.

https://doi.org/10.1080/08998280.2000.11927704

7. Katzung B, Masters S, Trevor A. Basic and Clinical Pharmacology. 2012; 12:770-772.

8. Tang TY, Li FZ, Afseth J. Review of the regulations for clinical research in herbal medicines in USA. Chin J Integr Med 2014; 20(12): 883-93.

https://doi.org/10.1007/s11655-014-2024-y

9. Gupta RK, Kesari AN, Murthy PS, Chandra R, Tandon V, Watal G. Hypoglycemic and antidiabetic effect of ethanolic extract of leaves of Annona squamosa L. in experimental animals. J Ethnoph 2005; 99(1):75-81. https://doi.org/10.1016/j.jep.2005.01.048

10. Ahmed D, Kumar V, Verma A, Shukla GS, Sharma M. Antidiabetic, antioxidant, antihyperlipidemic effect of extract of Euryale ferox salisb. with enhanced histopathology of pancreas, liver and kidney in streptozotocin induced diabetic rats. Springerplus 2015; 4: 315. https://doi.org/10.1186/s40064-015-1059-7

11. Bellakhdar J. La pharmacopée Marocain Traditionnelle. Médecin Arabe Anciennet et Savoirs populaires, Ibis Prés, Paris, in Revue d'histoire de la pharmacie, Persée - Portail des revues scientifiques en SHS 1997;86:764. https://doi.org/10.22270/ujpr.v3i5.194

12. Milburn M. Dragon's blood in east and west Africa, Arabian and The Canary Islands. Africa (Lond) 1984; 39: 486-493. https://doi.org/10.1016/j.jep.2007.10.018

13. Stern WT. Dictionary of Plant Names for Gardeners. London: Cassell Publishers Ltd., 1992.

14. Mothana RAA, Mentel R, Reiss C, Lindequist U. Phytochemical screening and antiviral activity of some medicinal plants from the island Soqotra. Phytother Res 2006; 20(4):298-302. https://doi.org/10.1002/ptr.1858

15. Vachálková A, Novotný L, Nejedlíková M, Suchý V. Potential carcinogenicity of homoisoflavanoids and flavonoids from Resina sanguinis draconis (Dracaena cinnabari Balf.). Neoplasma 1995; 42(6):313-6. PMID: 8592573

16. Liu X. Effects of dragon? blood resin and its component loureirin B on tetrodotoxin-sensitive voltage-gated sodium currents in rat dorsal root ganglion neurons. Sci China Ser. C 2004; 47(4):340. https://doi.org/10.1360/03yc0146
17. Juránek I, Suchý V, Stará D, Maśterova I, Grancaiová Z. Antioxidative activity of homoisoflavonoids from Muscari racemosum and Dracena cinnabari. Pharmazie 1993; 48(4): 310-1. PMID: 8321885

18. Alwashli A, Alaoui K, Al-Sobarry M. Anti-inflammatory and Analgesic effects of ethanolic extract of Dracaena cinnabri Balf as endemic plant in Yemen. Int J Pharma Bio Sci 2012; 3(2): 96-106. https://doi.org/10.1.1.587.1239

19. Mohammed YHE, Khanum SA. Anti-Diabetic Activity of Dracaen cinnabari Balf Extracts from Resin in Socotra Island-Yemen. J Plant Biochem Physiol 2016; 4:1. https://doi.org/10.4172/2329-9029.1000162

20. Prince PSM, Menon VP, Pari L. Hypoglycaemic activity of Syzigium cumini seeds: effect on lipid peroxidation in alloxan diabetic rats. J Ethnopharmacol 1998; 61(1):1-7. https://doi.org/10.1016/S0378-8741(98)00002-6

21. Dhandapani S, Subramanian VR, Rajagopal S, Namasivayam N. Hypolipidemic Effect of Cuminum cyminum L. On Alloxan-Induced Diabetic Rats. Pharmacol Res 2002; 46(3):251-255. https://doi.org/10.1016/S1043-6618(02)00131-7

22. El-Hilaly J, Tahraoui A, Israili ZH, Lyoussi B. Hypolipidemic effects of acute and sub-chronic administration of an aqueous extract of Ajuga iva L. whole plant in normal and diabetic rats. J Ethnopharmacol 2006; 105(3): 441-8. https://doi.org/10.1016/j.jep.2005.11.023

23. Gu HJ, Lv JC, Yong KL, Chen X, Liu PP, Zhang XB. Antidiabetic effect of an active fraction extracted from dragon's blood (Dracaena cochinchinensis). J Enzyme Inhib Med Chem 2009; 24(1):136-9. https://doi.org/10.1080/14756360801936399

24. Datta A, Bagchi C, Das S, Mitra A, De Pati A, Tripathi SK. Antidiabetic and antihyperlipidemic activity of hydroalcoholic extract of Withania coagulans Dunal dried fruit in experimental rat models. J Ayurveda Integr Med 2013; 4(2):99-106. https://doi.org/10.4103/0975-9476.113880

25. Mohan H. Harsh Mohan - Pathology Practical Book, $2^{\text {nd }}$ Edition.pdf - Google Drive. The Indian J Pathol Micro 2007.

26. Sharaf K, Ali J Hypolipedemic effect of Kuub (Gundelia tournefotii A.) oil and clofibrate on lipid profile of atheroscherotic rats. Vet Arh 2004; 74(5): 359-369. https://doi.org/10.3923/pjbs.2013.1238.1247

27. Gosain S, et al. Hypolipidemic effect of ethanolic extract from the leaves of Hibiscus sabdariffa L. in hyperlipidemic rats. Acta Pol Pharm 2010; 67(2):179-84. PMID: 20369795

28. Friedewald WT, Levy RI, Fredrickson DS. Estimation of the concentration of low-density lipoprotein cholesterol in plasma, without use of the preparative ultracentrifuge. Clin. Chem 1972; 18(6):499-502. https://doi.org/10.1093/clinchem/18.6.499

29. Lenzen S. The mechanisms of alloxan- and streptozotocininduced diabetes. Diabetologia 2008; 51(2):216-26. https://doi.org/10.1007/s00125-007-0886-7

30. Dhanabal SP, Raja MKMM, Ramanathan M, Suresh B. Hypoglycemic activity of Nymphaea stellata leaves ethanolic extract in alloxan induced diabetic rats. Fitoterapia. 2007; 78(4): 288-91. https://doi.org/10.1016/j.fitote.2007.02.009

31. F. Chen, H. Xiong, J. Wang, X. Ding, G. Shu, Z. Mei, Antidiabetic effect of total flavonoids from Sanguis draxonis in type 2 diabetic rats. J Ethnopharmacol 2013; 149(3):,729-36. https://doi.org/10.1016/j.jep.2013.07.035

32. Al-Qattan K, Thomson M, Ali M. Garlic (Allium sativum) and ginger (Zingiber officinale) attenuate structural nephropathy progression in streptozotocin-induced diabetic rats. E Spen Eur E J Clin Nutr Metab 2008; 3(2):e62-e71. https://doi.org/10.1016/j.eclnm.2007.12.001

33. Gupta D, Bleakley B, Gupta RK. Dragon's blood: Botany, chemistry and therapeutic uses. J Ethnopharmacol 2007; 115:361-380. https://doi.org/10.1016/j.jep.2007.10.018

34. Fan JY, et al. A systematic review of the botanical, phytochemical and pharmacological profile of Dracaena 
cochinchinensis, a plant source of the ethnomedicine 'dragon's blood. Molecules 2014;19(7):10650-69. https://doi.org/10.3390/molecules 190710650

35. Choi JS, Yokozawa T, Oura H. Improvement of hyperglycemia and hyperlipemia in streptozotocin-diabetic rats by a methanolic extract of Prunus davidiana stems and its main component, prunin. Planta Med 1991; 57(3):20811. https://doi.org/10.1055/s-2006-960075

36. Kamalakkannan N, Prince PSM. Antihyperglycaemic and antioxidant effect of rutin, a polyphenolic flavonoid, in streptozotocin-induced diabetic wistar rats. Basic Clin. Pharmacol Toxicol 2006; 98(1): 97-103. https://doi.org/10.1111/j.1742-7843.2006.pto_241.x

37. Jung UJ, Lee MK, Jeong KS, Choi MS. The hypoglycemic effects of hesperidin and naringin are partly mediated by hepatic glucose-regulating enzymes in C57BL/KsJ-db/db mice. J Nutr 2004; 134(10):2499-503. https://doi.org/10.1093/jn/134.10.2499

38. Kawabata J, Mizuhata K, Sato E, Nishioka T, Aoyama Y, Kasai T. 6-hydroxyflavonoids as alpha-glucosidase inhibitors from marjoram (Origanum majorana) leaves. Biosci Biotechnol Biochem 2003; 67(2):445-7. https://doi.org/10.1271/bbb.67.445

39. Andrade-Cetto A, Wiedenfeld H. Hypoglycemic effect of Cecropia obtusifolia on streptozotocin diabetic rats. J Ethnopharmacol 2001; 78(2-3):145-9. https://doi.org/10.1016/S0378-8741(01)00335-X

40. Matsuda H, Nishida N, Yoshikawa M. Antidiabetic principles of natural medicines. V. Aldose reductase inhibitors from Myrcia multiflora DC. (2): Structures of myrciacitrins III, IV, and V. Chem Pharm Bull (Tokyo) 2002; 50(3):429-31. https://doi.org/10.1248/cpb.50.429

41. Narvaez-Mastache JM, Garduño-Ramírez ML, Alvarez L, Delgado G. Antihyperglycemic activity and chemical constituents of Eysenhardtia platycarpa. J Nat Prod 2006; 69(12):1687-91. https://doi.org/10.1021/np060166z.

42. Kim HY, Moon BH, Lee HJ, Choi DH. Flavonol glycosides from the leaves of Eucommia ulmoides O. with glycation inhibitory activity. J Ethnopharmacol 2004; 93(2-3):22730. https://doi.org/10.1016/j.jep.2004.03.047

43. Pinent M, Castell A, Baiges I, Montagut G, Arola L, Ardévol A. Bioactivity of flavonoids on insulin-secreting cells. Compr Rev Food Sci Food Saf 2008; 7(4):299-308. https://doi.org/10.1007/s11130-016-0571-4

44. Distefano JK, Watanabe RM. Pharmacogenetics of antidiabetes drugs. Pharmaceuticals (Basel) 2010; 3(8):26102646. https://doi.org/10.3390/ph3082610
45. Johansen JS, Harris AK, Rychly DJ, Ergul A. Oxidative stress and the use of antioxidants in diabetes: linking basic science to clinical practice. Cardiovasc Diabetol 2005;4: 5. https://dx.doi.org/10.1186\%2F1475-2840-4-5

46. Abu-Taleb Y, Alzowahi F, Tukaram K, Shaikh R. In vitro evaluation of antimicrobial and antioxidant activity of Dragon's blood tree (Dracaena cinnabari Balf) of Socotra Island (Yemen). J Coast Life Med 2013; 123-129. https://doi.org/10.1186/1472-6882-11-13

47. Gupta D, Gupta RK. Bioprotective properties of Dragon's blood resin: in vitro evaluation of antioxidant activity and antimicrobial activity. BMC Complement Altern Med. 2011; 11(1):13. https://doi.org/10.1186/1472-6882-11-13

48. Pietta PG. Flavonoids as antioxidants. J Nat Prod 2000; 63(7):1035-42. https://doi.org/10.1021/np9904509

49. Koffi N, Ernest A, Dodiomon S. Effect of aqueous extract of Persea Americana Seeds on the glycemia of diabetic rabbits. Eur J Sci Res 2009; 26(3):376.

50. Yasir M, Das S, Kharya MD. The phytochemical and pharmacological profile of Persea Americana Mill. Pharmacogn Rev 2010; 4(7):77-84. https://doi.org/10.4103/0973-7847.65332

51. Liu H, Guz Y, Kedees MH, Winkler J, Teitelman G. Precursor cells in mouse islets generate new beta-cells in vivo during aging and after islet injury. Endocrinol 2010; 151(2):520-8. https://doi.org/10.1210/en.2009-0992

52. Syiem D, Syngai G, Khup PZ, Khongwir BS, Kharbuli B, Kayang H. Hypoglycemic effects of Potentilla fulgens L in normal and alloxan-induced diabetic mice. J Ethnopharmacol 2002; 83(1-2):55-61. https://doi.org/10.1016/S0378-8741(02)00190-3

53. Tania O, Kelly R, Márcia A, Marcelo C, Tanus N. Hypolipidemic Effect of flavonoids and cholestyramine in rats. Lat Am J Pharm 2007; 26 (3):407-10.

54. Ngamukote S, Mäkynen K, Thilawech T, Adisakwattana S. Cholesterol-lowering activity of the major polyphenols in grape seed. Molecules 2011; 16(6):5054-61. https://doi.org/10.3390/molecules 16065054

55. Sivashanmugam T, et al. Discovery of potential cholesterol esterase inhibitors using in silico docking studies. Bangladesh J Pharmacol 2013; 8(3):223-229. https://doi.org/10.3329/bjp.v8i3.14521

56. Chávez-Santoscoy RA, Gutiérrez-Uribe JA, Serna-Saldívar SO. Effect of flavonoids and saponins extracted from black bean (Phaseolus vulgaris L.) seed coats as cholesterol micelle disruptors. Plant Foods Hum Nutr 2013; 68(4): 416-23. $\quad$ https://doi.org/10.1017/S0007114514001536 